\title{
Epigenetic changes induced by curcumin and other natural compounds
}

\author{
Simone Reuter $\cdot$ Subash C. Gupta $\cdot$ \\ Byoungduck Park $\cdot$ Ajay Goel $\cdot$ Bharat B. Aggarwal
}

Received: 1 February 2011/Accepted: 5 April 2011/Published online: 24 April 2011

(C) Springer-Verlag 2011

\begin{abstract}
Epigenetic regulation, which includes changes in DNA methylation, histone modifications, and alteration in microRNA (miRNA) expression without any change in the DNA sequence, constitutes an important mechanism by which dietary components can selectively activate or inactivate gene expression. Curcumin (diferuloylmethane), a component of the golden spice Curcuma longa, commonly known as turmeric, has recently been determined to induce epigenetic changes. This review summarizes current knowledge about the effect of curcumin on the regulation of histone deacetylases, histone acetyltransferases, DNA methyltransferase I, and miRNAs. How these changes lead to modulation of gene expression is also discussed. We also discuss other nutraceuticals which exhibit similar properties. The development of curcumin for clinical use as a regulator of epigenetic changes, however, needs further investigation to determine novel and effective chemopreventive strategies, either alone or in combination with other anticancer agents, for improving cancer treatment.
\end{abstract}

Keywords Curcumin - Epigenetics - Histone acetyltransferase $\cdot$ Histone deacetyltransferase $\cdot$ DNA methyltransferase $\cdot$ microRNA

S. Reuter · S. C. Gupta · B. Park · B. B. Aggarwal $(\square)$

Cytokine Research Laboratory,

Department of Experimental Therapeutics,

The University of Texas MD Anderson Cancer Center,

Houston, TX 77030, USA

e-mail: aggarwal@mdanderson.org

\section{A. Goel}

Gastrointestinal Cancer Research Laboratory Baylor Research Institute, Baylor University Medical Center,

Dallas, TX 75246, USA

\section{Introduction}

Epigenetics, heritable changes in gene expression that occur without a change in the DNA sequence, constitute an important mechanism by which dietary components can selectively activate or inactivate gene expression (Davis and Ross 2007). Epigenetic mechanisms include changes in DNA methylation, histone modifications, and altered microRNA (miRNA) expression (Yoo and Jones 2006; Winter et al. 2009).

Changes to the structure of chromatin influence gene expression by either inactivating genes, which occurs when the chromatin is closed (heterochromatin), or by activating genes when the chromatin is open (euchromatin) (Rodenhiser and Mann 2006). The nucleosome (Fig. 1a), which is the fundamental repeating unit of chromatin, is composed of DNA wrapped around a histone octamer, formed by four histone partners, an $\mathrm{H} 3-\mathrm{H} 4$ tetramer, and two H2A-H2B-dimers. Each successive nucleosomal core is separated by a DNA linker associated with a single molecule of histone H1. Chromatin modifications usually occur at the amino acids of the $\mathrm{N}$-terminal tails of histones (Fig. 1b) and either facilitate or hinder the association of DNA repair proteins and transcription factors with chromatin. These core histones undergo a wide range of post-translational modifications, including acetylation, controlled by histone acetyltransferases (HATs), and associated with gene expression (Zhang and Dent 2005); deacetylation, controlled by histone deacetylases (HDACs), and associated with gene inactivation; and methylation, phosphorylation, ubiquitination, sumoylation, ADP-ribosylation, and possibly biotinylation (Davis and Ross 2007).

In addition, epigenetic factors can also affect the expression of miRNAs (Croce 2009). Aberrant expression 
Fig. 1 a The fundamental repeating unit of the chromatin is the nucleosome. A single nucleosomal core is composed of a DNA fragment wrapped around a histone octamer, formed by an $\mathrm{H} 3-\mathrm{H} 4$ tetramer and two H2A-H2B dimers. Each successive nucleosomal core is separated by a DNA linker associated with a single molecule of histone $\mathrm{H} 1$. b Chromatin modifications usually occur at the amino acids of the N-terminal tails of histones. These histone tails are the site for a wide range of posttranslational modifications, including acetylation controlled by histone acetyltransferases (HATs), deacetylation controlled by histone deacetylases (HDACs), and methylation controlled by DNA methyltransferases (DNMTs)
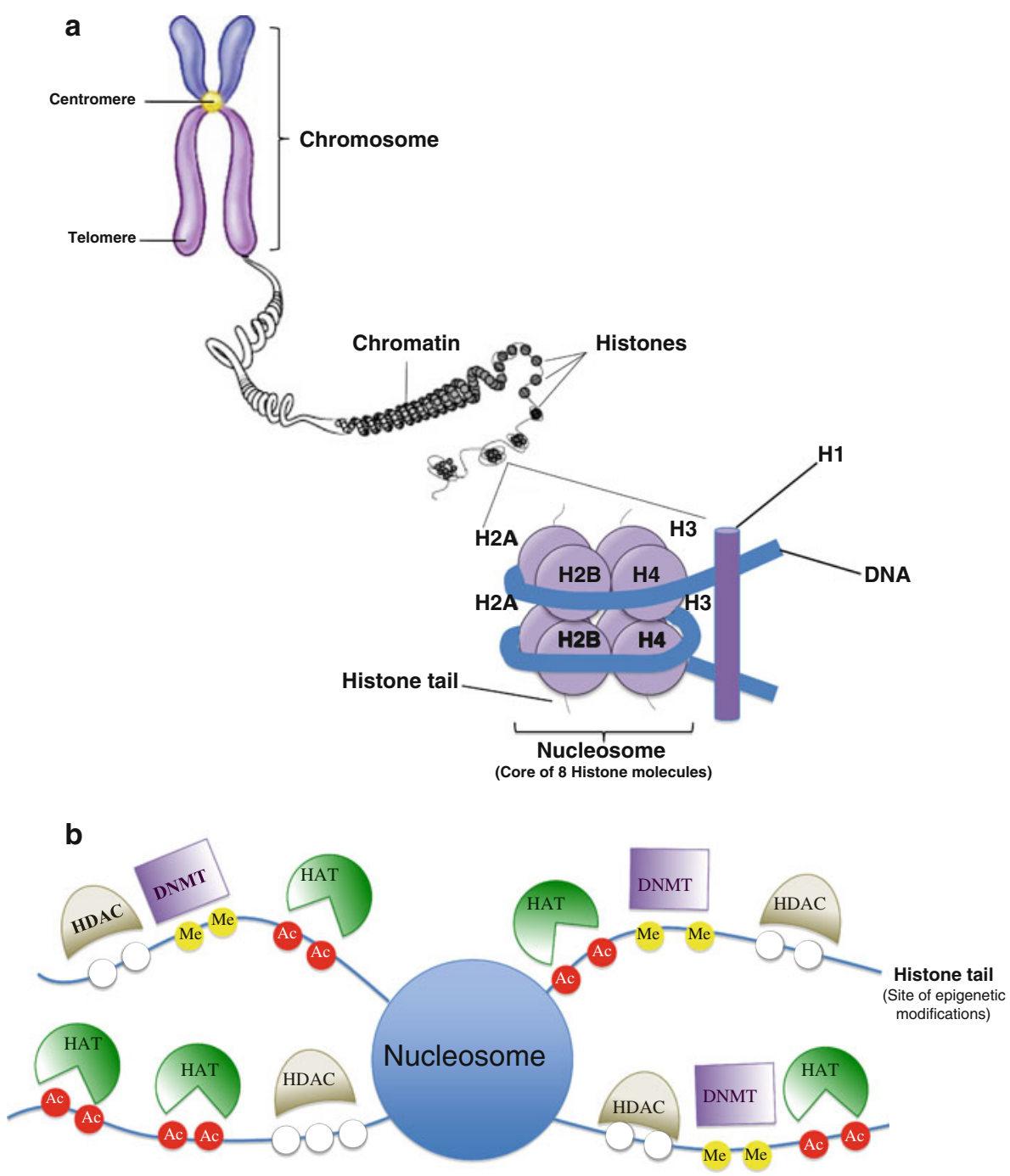

of miRNAs can arise through numerous mechanisms, including genomic abnormalities, transcriptional regulation, and processing of miRNAs (Winter et al. 2009). miRNAs are small, endogenous, single-stranded RNAs of 19-25 nucleotides in length that regulate gene expression, for example, by binding imperfectly to the $3^{\prime}$ untranslated region of target $\mathrm{mRNAs}$, leading to translational repression, or by targeting mRNA cleavage because of the imperfect complementarity between miRNA and mRNA.

Recently, natural compounds, such as curcumin, epigallocatechin gallate (EGCG), and resveratrol, have been shown to alter epigenetic mechanisms, which may lead to increased sensitivity of cancer cells to conventional agents and thus inhibition of tumor growth (Li et al. 2010). Curcumin (diferuloylmethane), a yellow spice and the active component of the perennial herb Curcuma longa, commonly known as turmeric (Aggarwal and Sung 2009), is one of the most powerful and promising chemopreventive and anticancer agents, and epidemiological evidence demonstrates that people who incorporate high doses of this spice in their diets have a lower incidence of cancer (Wargovich 1997). Furthermore, epidemiological evidence exists indicating that there is a correlation between increased dietary intake of antioxidants and a lower incidence of morbidity and mortality (Devasagayam et al. 2004). For instance, a population-based case-control study in approximately 500 newly diagnosed gastric adenocarcinoma patients and approximately 1,100 control subjects in Sweden found that the total antioxidant potential of several plant-based dietary components was inversely associated with gastric cancer risk (Serafini et al. 2002).

Dietary and other environmental factors induce epigenetic alterations which may have important consequences for cancer development (Penn et al. 2009). Butyrate was the first food-derived substance shown to affect posttranslational modifications of histones through its action as an inhibitor of class 1 HDACs (Davie 2003; Kruh 1982; Vidali et al. 1978). More recently, a number of other 


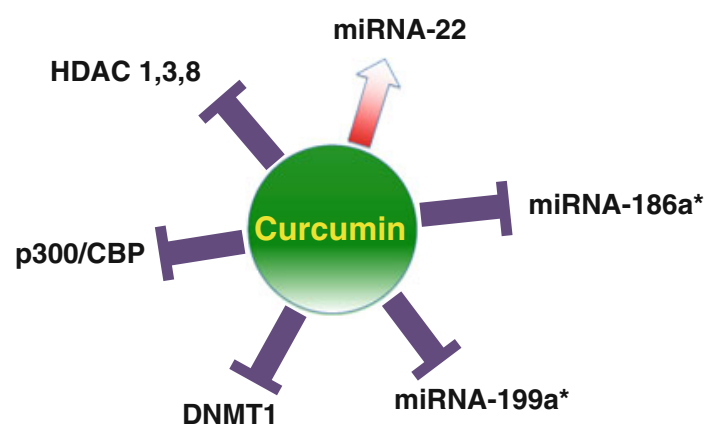

Fig. 2 Schematic representation of epigenetic factors modulated by curcumin

dietary components have been identified which modulate the acetylation state of histones or affect the activities of HDACs and/or histone acetyl transferases [reviewed by Delage and Dashwood (2008)]. Proof of principle that dietary exposures may have lifelong consequences for epigenetic marks comes from recent studies of the adult offspring of women exposed to famine during pregnancy. Methylation of the imprinted gene insulin-like growth factor 2 was lower in adults (approximately 60 years of age) who were periconceptionally exposed to famine during the Dutch Hunger Winter of 1944-1945 (Heijmans et al. 2008). Interest in the effects of dietary compounds such as resveratrol which activate class III HDACs (sirtuins) is growing rapidly because of their demonstrable role in extending lifespan and in reducing, or delaying, age-related diseases including cancers (Baur 2010).

How curcumin exerts its powerful anticancer activities has been thoroughly investigated, and several mechanisms of action have been discovered. Although pharmacokinetic studies have shown that curcumin is present in much lower plasma concentration in humans than in vitro, numerous preclinical reports have demonstrated curcumin's anticancer activity (Sharma et al. 2004; Cheng et al. 2001). One explanation for its activity in humans, even at lower concentrations, might be that curcumin exerts its biological activities through epigenetic modulation (Fig. 2).

\section{Effect of curcumin on histone acetylation/deacetylation}

Histone modifications are among the most important epigenetic changes, because it can alter gene expression and modify cancer risk (Gibbons 2005). Abnormal activity of both HATs and HDACs has been linked to the pathogenesis of cancer. HDACs are a class of enzymes that remove acetyl groups from an $\varepsilon-N$-acetyl lysine amino acid on a histone. Its action is opposite to that of HATs. HDAC enzymes do not bind to DNA directly but rather interact with DNA through multiprotein complexes that include corepressors and coactivators. At least 18 HDACs have been identified in humans, primarily occupying 4 classes based on homology with yeast deacetylases (Xu et al. 2007). HDAC inhibitors are being explored as cancer therapeutic compounds because of their ability to alter several cellular functions known to be deregulated in cancer cells (Davis and Ross 2007).

Recently, various studies have investigated the effect of curcumin on HDAC expression. Of these, Bora-Tatar et al. (2009) reported that among 33 carboxylic acid derivatives, curcumin was the most effective HDAC inhibitor, and that it was even more potent than valproic acid and sodium butyrate, which are well-known HDAC inhibitors. Another study revealed that HDAC 1, 3, and 8 protein levels were significantly decreased by curcumin, resulting in increased levels of acetylated histone H4 (Liu et al. 2005). Similarly, significant decreases in the amounts of HDAC1 and HDAC3 were detected by Chen et al. (2007) after treatment with curcumin.

By contrast, HDAC2, a critical component of corticosteroid anti-inflammatory action and impaired in lungs of patients with chronic obstructive pulmonary disease and by cigarette smoke extract, was restored by curcumin (Meja et al. 2008). Because of the differing effect of curcumin on the different subtypes of HDAC enzymes, further research is required to understand the mechanism of curcumin on HDAC expression.

HATs, enzymes that acetylate conserved lysine amino acids on histone proteins by transferring an acetyl group from acetyl $\mathrm{CoA}$ to form $\varepsilon-N$-acetyl lysine, are other important targets for dietary components. HATs include at least 25 members and are organized into 4 families based on primary structure homology (Lee and Workman 2007). Several studies have recently reported that curcumin is a potent HAT inhibitor. In 2004, Balasubramanyam et al. (2004) reported that curcumin is a specific inhibitor of p300/CREB-binding protein (CBP) HAT activity in vitro and in vivo but not of p300/CBP-associated factor. Furthermore, they showed that curcumin inhibited the p300-mediated acetylation of p53 in vivo and significantly repressed acetylation of HIV-Tat protein in vitro as well as proliferation of the virus (Balasubramanyam et al. 2004).

Another group that identified curcumin as a specific inhibitor of p300/CBP HAT activity in vitro and in vivo discovered that inhibition of p300 HAT activity by curcumin prevented also against heart failure in rats (Morimoto et al. 2008). Marcu et al. (2006) found that curcumin's binding site on $\mathrm{p} 300 / \mathrm{CBP}$ was specific and that binding led to a conformational change, resulting in a decrease in the binding efficiency of histones $\mathrm{H} 3$ and $\mathrm{H} 4$ and acetyl CoA.

It is well known that curcumin induces apoptosis of numerous cancer cell lines, but its mechanism may vary. 
Induction of apoptosis by curcumin in cervical cancer cells, for example, was associated with inhibition of histone and p53 acetylation through specific inhibition of p300/CBP (Balasubramanyam et al. 2004). For example, curcumin activated poly (ADP) ribose polymerase- and caspase-3mediated apoptosis in brain glioma cells through induction of histone hypoacetylation (Kang et al. 2006).

Histones are acetylated and deacetylated on lysine residues, but HATs and HDACs can also modify the acetylation status of non-histone proteins (Sadoul et al. 2008). The regulation of transcription factors, effector proteins, molecular chaperones, and cytoskeletal proteins by acetylation/deacetylation is emerging as a significant posttranslational regulatory mechanism (Glozak et al. 2005).

NF- $\kappa \mathrm{B}$, a pro-inflammatory transcription factor, undergoes acetylation before it activates hundreds of genes involved in different cellular processes (Chen et al. 2001; Gupta et al. 2010a). Acetylation of NF- $\kappa$ B takes place at multiple lysine residues with the p300/CBP acetyltransferases. Curcumin inhibited p300-mediated acetylation of RelA, an isoform of NF- $\kappa \mathrm{B}$, which attenuated interaction with $\mathrm{I} \kappa \mathrm{B} \alpha$, leading to decreased $\mathrm{I} \kappa \mathrm{B} \alpha$-dependent nuclear export of the complex through a chromosomal region maintenance-1-dependent pathway (Chen et al. 2001). In the same way, Yun et al. (2010) found that curcumin treatment significantly reduced HAT activity, p300 levels, and acetylated $\mathrm{CBP} / \mathrm{p} 300$ gene expression and consequently suppressed NF- $\kappa \mathrm{B}$ binding. Thus, curcumin's ability to suppress p300/CBP HAT activity may be responsible, at least in part, for its potent NF- $\kappa \mathrm{B}$ inhibitory activity.

Curcumin also inhibited the hypertrophy-induced acetylation and DNA-binding abilities of GATA4, a hypertrophy-responsive transcription factor, in rat cardiomyocytes, which indicates that inhibition of p300 HAT activity by curcumin may also provide a novel therapeutic strategy for heart failure in humans (Morimoto et al. 2008). Finally, curcumin also induced recontrolling of neural stem cell fates by decreasing histone $\mathrm{H} 3$ and $\mathrm{H} 4$ acetylation (Kang et al. 2006).

Since curcumin can modulate both HDAC and HAT, a common mechanism may be underlying. For example, oxidative stress can activate NF- $\kappa \mathrm{B}$ through the activation of intrinsic HAT activity, resulting in the expression of proinflammatory mediators, but it can also inhibit HDAC activity (Rahman et al. 2004). As such, curcumin, a known antioxidant, may regulate both acetylation and deacetylation through the modulation of oxidative stress.

\section{Effect of curcumin on DNA methylation}

DNA methylation plays an essential role in regulating normal biological processes in addition to carcinogenesis
(Esteller 2007). DNA methylation is a heritable modification of the DNA structure that does not alter the specific sequence of base pairs responsible for encoding the genome but that can directly inhibit gene expression (Das and Singal 2004). Two patterns of DNA methylation have been observed in cancer cells: global hypomethylation, or decreased methylation that can facilitate the expression of quiescent proto-oncogenes and prometastatic genes and promote tumor progression, or localized hypermethylation, an increased methylation at specific $\mathrm{CpG}$ islands within the gene promoter regions of specific genes, such as tumor suppressor genes, that can result in transcriptional silencing and an inability to control tumorigenesis (Ehrlich 2009). DNA methylation is regulated by DNA methyltransferases (DNMT1, DNMT3a, and DNMT3b) in the presence of S-adenosyl-methionine, which serves as a methyl donor for methylation of cytosine residues at the $\mathrm{C}-5$ position to yield 5-methylcytosine (Herman and Baylin 2003).

Only a few reports have so far investigated the effect of curcumin on DNA methylation. Molecular docking of the interaction between curcumin and DNMT1 suggested that curcumin covalently blocks the catalytic thiolate of DNMT1 to exert its inhibitory effect on DNA methylation (Liu et al. 2009). However, a more recent study showed no curcumin-dependent demethylation, which suggested that curcumin has little or no pharmacologically relevant activity as a DNMT inhibitor (Medina-Franco et al. 2010). To clarify these contradictions, more research is urgently needed.

Given that 5-azacitidine and decitabine, two FDAapproved hypomethylating agents for treating myelodysplastic syndrome, have a demonstrated ability to sensitize cancer cells to chemotherapeutic agents, it would be worthwhile to explore whether the hypomethylation effect of curcumin can also induce cancer cell chemosensitization. Interestingly, a phase 1 trial with curcumin administered several days before docetaxel in patients with metastatic breast cancer resulted in 5 partial remissions and stable disease in 3 of 8 patients (Bayet-Robert et al. 2011). This unexpected high response might have resulted from the clever sequential delivery of these two agents, which capitalized on and maximized curcumin's epigenetic activity for cancer treatment.

\section{Effect of curcumin on miRNA expression}

miRNAs, small noncoding regulatory RNAs, range in size from 17 to 25 nucleotides (Croce 2009) and are responsible for a reduced translation rate and/or increased degradation of mRNAs if aberrantly expressed. miRNAs play important roles in cell cycling, programmed cell death, cell differentiation, tumor development, invasion, metastasis, and 
angiogenesis (Negrini et al. 2007). To date, more than 500 human miRNA genes have been identified, and it is believed that at least 500 have yet to be discovered within the human genome (Bentwich et al. 2005). The specific function of most mammalian miRNAs is still unknown (Bentwich et al. 2005), but it is speculated that miRNAs could regulate $\sim 30 \%$ of the human genome (Bartel 2004). Disturbances in the expression of miRNAs, processing of miRNA precursors, or mutations in the sequence of the miRNA, its precursor, or its target mRNA may have detrimental effects on cellular function and have been associated with cancer (Davis and Ross 2008). Some miRNAs could, for example, regulate the formation of cancer stem cells and the epithelial-mesenchymal transition (EMT) phenotype of cancer cells, which are typically drug resistant (Li et al. 2010).

It is known that curcumin regulates the expression of genes that are critically involved in the regulation of cellular signaling pathways, including NF- $\kappa \mathrm{B}$, Akt, MAPK, and other pathways (Mukhopadhyay et al. 2001; Sarkar and Li 2004). These signaling pathways could be regulated by miRNAs.

Recently, Sun et al. (2008) reported that curcumin altered miRNA expression in human pancreatic cancer cells. After $72 \mathrm{~h}$ of incubation, 11 miRNAs were significantly up-regulated and 18 were down-regulated by curcumin. Among these, miRNA-22 was the most significantly up-regulated and miRNA-199a* the most down-regulated. Those researchers also found that up-regulation of miR-22 expression by curcumin suppressed the expression of its target genes Sp1 and estrogen receptor 1 (Sun et al. 2008). These results suggest that curcumin could inhibit the proliferation of pancreatic cancer cells through the regulation of specific miRNAs. In addition, curcumin has been shown to promote apoptosis in A549/DDP multidrug-resistant human lung adenocarcinoma cells through an miRNA signaling pathway (Zhang et al. 2010). In these cells, curcumin significantly down-regulated the expression of miR-186* (Zhang et al. 2010). A major challenge for current miRNA studies is to identify the biologically relevant downstream targets that they regulate. In the study by Sun et al. (2008) at least 50 target genes for miRNA-22 were found, showing that a key effect of curcumin on pancreatic cancer cells could be mediated by epigenetic modulation of miRNAs.

In addition, a recent report showed that gemcitabine sensitivity can be induced in pancreatic cancer cells through modulation of miR-200 and miR-21 expression by curcumin (Ali et al. 2010). The miR-200 family has been shown to inhibit the EMT, the initiating step of metastasis, by maintaining the epithelial phenotype through direct targeting of the transcriptional repressors of E-cadherin, ZEB1, and ZEB2 (Korpal and Kang 2008). Therefore, targeting specific miRNAs could be a novel therapeutic approach for the treatment of cancers, especially by eliminating cancer stem cells or EMT-type cells that are typically drug resistant. In contrast, miR-21 is an oncomiR and is overexpressed in many tumors, thereby promoting cancer progression and metastasis. Curcumin treatment has been shown to reduce miR-21 promoter activity and expression in primary tumors by inhibiting AP-1 binding to the promoter and to induce expression of the tumor suppressor Pdcd4, a target of miR-21 (Mudduluru et al. 2011).

These novel findings suggest that the use of natural agents could open new avenues for the successful treatment of cancers, especially by combining conventional therapeutics with natural chemopreventive agents that are known to be nontoxic to humans ( $\mathrm{Li}$ et al. 2010).

\section{Curcumin and DNA binding}

Curcumin's antioxidant (Miquel et al. 2002), anti-inflammatory (Surh 1999), antimicrobial (Saleheen et al. 2002; Taher et al. 2003), and chemopreventive (Aggarwal et al. 2003) properties are attributed to various mechanisms, including an anti-angiogenic action; up-regulation of enzymes detoxifying carcinogens, such as glutathione S-transferase; inhibition of signal transduction pathways critical for tumor cell growth (e.g., NF- $\kappa \mathrm{B}$ ); suppression of cyclooxygenase expression; and neutralization of carcinogenic free radicals (Aggarwal et al. 2003; Chauhan 2002; Itokawa et al. 2008). However, the molecular basis of curcumin's various therapeutic actions is far from established, perhaps because research has focused so far only on proteins as the potential macromolecular targets of curcumin and less on its ability to bind directly to the DNA and to modulate epigenetic mechanisms directly as a DNA binding agent.

In 2004, a direct interaction between curcumin and both natural and synthetic DNA duplexes was demonstrated by using circular dichroism and absorption spectroscopy techniques (Zsila et al. 2004). Evaluation of the spectral data and molecular modeling calculations suggested that curcumin binds to the minor groove of the double helix and that it is also a promising molecular probe to study biologically important $\mathrm{pH}$ - and cation-induced conformational polymorphisms of nucleic acids (Zsila et al. 2004). Based on these results, curcumin has to be considered as a new phenolic minor groove-binding agent, which may explain the observed anticancer potential and other pharmacological effects of this natural compound.

In the same way, Fourier transform infrared (FTIR) and UV analysis of the binding of curcumin to the DNA showed that curcumin can bind to the major and minor grooves of the DNA duplex, to RNA bases, and to the 
backbone phosphate group (Nafisi et al. 2009). No conformational changes were observed upon the interaction between curcumin and these biopolymers. Instead, Nafisi et al. (2009) found that curcumin binds to DNA through thymine $\mathrm{O}_{2}$ in the minor groove and through guanine and adenine N7 in the major groove, as well as to the backbone $\mathrm{PO}_{2}$ group. RNA binding occurs via uracil $\mathrm{O}_{2}$ and guanine and adenine $\mathrm{N} 7$ atoms as well as the backbone phosphate group. Interestingly, the interaction of curcumin was stronger with DNA than RNA.

Pentamidine, a diarylamidine antibiotic that is currently in clinical use for treatment of leishmaniasis, trypanosomiasis, and Pneumocystis carinii pneumonia (Fairlamb 2003), has been suggested to interact directly with the pathogenic genome. It binds selectively to the minor groove of the DNA, similar to curcumin, and interferes with the normal functioning of the pathogen topoisomerases (Reddy et al. 1999; Neidle 2001; Bischoff and Hoffmann 2002). Interestingly, curcumin was also found to be effective against trypanosomiasis (Saleheen et al. 2002; Araujo and Leon 2001), which could be due to its binding ability to the minor groove of the DNA.

\section{Effect of curcumin on transcription factors}

Extensive research over the past five decades has indicated that curcumin reduces blood cholesterol levels; prevents low-density lipoprotein oxidation; inhibits platelet aggregation; suppresses thrombosis and myocardial infarction; suppresses symptoms associated with type II diabetes, rheumatoid arthritis, multiple sclerosis, and Alzheimer disease; inhibits HIV replication; suppresses tumor formation; enhances wound healing; protects against liver injury; increases bile secretion; protects against cataract formation; and protects against pulmonary toxicity and fibrosis (Shishodia et al. 2007). These divergent effects of curcumin seem to depend on its pleiotropic molecular effects, including the regulation of signal transduction pathways, and direct modulation of several enzymatic activities. Most of these signaling cascades lead to the activation of transcription factors.

Transcription factors are proteins that bind to DNA at a specific promoter or enhancer region, probably at histone tails, which are considered to be the platform for transcription factors (Fig. 1b), and thus regulate the expression of various genes. Hundreds of transcription factors with functionally different domains essential for DNA binding and activation have been identified and characterized in several organisms-some of the transcription factors are important targets for therapeutic intervention in several types of disease (Shishodia et al. 2007). For example, the transcription factors NF- $\kappa \mathrm{B}$, activator protein (AP) -1 , and
Signal transducer and activator of transcription (STAT) control the expression of genes that affect cell transformation, proliferation, cell survival, invasion, metastasis, adhesion, angiogenesis, and apoptosis (Aggarwal 2004; Aggarwal et al. 2009; Gupta et al. 2010b; Shishodia and Aggarwal 2004). Other transcription factors involved in cancer are early growth response-1 (Egr-1), peroxisome proliferator-activated receptor- $\gamma$ (PPAR- $\gamma$ ), electrophile response element (EpRE), $\beta$-catenin, NF-E2-related factor 2 (Nrf2), and androgen receptor (AR).

Our laboratory has previously shown that curcumin down-regulates the activation of NF- $\kappa \mathrm{B}$ by various tumor promoters, including phorbol ester, tumor necrosis factor, hydrogen peroxide, and cigarette smoke (Shishodia et al. 2003; Singh and Aggarwal 1995). Curcumin-induced down-regulation of NF- $\kappa \mathrm{B}$ was shown to be mediated through suppressed activation of $\mathrm{I} \kappa \mathrm{B} \alpha$ kinase (IKK) (Shishodia et al. 2003; Jobin et al. 1999; Plummer et al. 1999). Moreover, curcumin can suppress constitutively active NF- $\kappa \mathrm{B}$ in mantle cell lymphoma through the suppression of IKK (Shishodia et al. 2005). This leads to the down-regulation of cyclin D1, cyclooxygenase-2, and matrix metalloproteinase-9. Also, we found that curcumin suppressed the paclitaxel-induced NF- $\kappa$ B pathway in breast cancer cells and inhibits lung metastasis of human breast cancer in nude mice (Aggarwal et al. 2005).

AP-1 has also been closely linked with the proliferation and transformation of tumor cells (Karin et al. 1997). Curcumin has been shown to inhibit the activation of AP-1 induced by tumor promoters (Huang et al. 1991) and JNK activation by carcinogens (Chen and Tan 1998). Bierhaus et al. (1997) demonstrated that curcumin-induced inhibition of AP-1 was due to its direct interaction with the AP-1 DNA-binding motif.

Curcumin was also shown to modulate STATs, and constitutive STAT activation can be observed in a large number of tumors. Curcumin inhibited both NF- $\kappa \mathrm{B}$ and STAT3 activation, leading to decreased expression of proteins involved in cell proliferation and apoptosis, such as Bcl-2, Bcl-xL, c-FLIP, XIAP, c-IAP1, survivin, c-Myc, and cyclin D1 (Mackenzie et al. 2008). The constitutive phosphorylation of STAT3 found in certain multiple myeloma cells was abrogated by treatment with curcumin (Bharti et al. 2003), and inhibition of STAT3 by curcumin led to the induction of apoptosis (Bharti et al. 2004). In addition, curcumin has been shown to modulate the Egr-1, PPAR- $\gamma$, EpRE, $\beta$-catenin, Nrf- 2 , and AR signaling pathways (Shishodia et al. 2003).

The evidence that curcumin modulates many important transcription factors, which are either constitutively expressed or overexpressed in cancer cells, might explain in part the molecular basis of the wide and complex effects of this phytochemical. The versatile chemical structure of 
curcumin enables it to interact with a large number of molecules inside the cell, leading to a variety of biological effects, such as modulation of the cell cycle, suppression of growth, induction of differentiation, up-regulation of proapoptotic factors, and inhibition of reactive oxygen species production.

\section{Effect of other natural compounds on epigenetics}

Evidence in the past decade has provided important clues that natural compounds present in plants and/or in the diet directly influence epigenetic mechanisms in humans (Table 1). Indeed, some dietary polyphenols may exert their chemopreventive effects in part by modulating various components of the epigenetic machinery in humans (Link et al. 2010).

EGCG, the ester of epigallocatechin and gallic acid and the major polyphenol in green tea, has been extensively studied as a potential demethylating agent. It has been hypothesized that generation of S-adenosyls-homocysteine, a potent inhibitor of DNA methylation, is one of the mechanisms for the demethylating properties of this compound. EGCG can form hydrogen bonds with different residues in the catalytic pocket of DNMT and thus act as a direct inhibitor of DNMT1 (Fang et al. 2003; Lee et al. 2005). EGCG has also been recently found to modulate miRNA expression in human hepatocellular carcinoma HepG2 cells. Tsang and Kwok performed microarray analysis in this cell line after EGCG treatment and found that the compound modified the expression of 61 miRNAs (Tsang and Kwok 2010).

Choi et al. found that another compound, gallic acid-an organic acid found in gallnuts, sumac, witch hazel, tea leaves, oak bark, and other plants can inhibit p300-induced p65 acetylation, increase the level of cytosolic $\mathrm{I} \kappa \mathrm{B} \alpha$, prevent lipopolysaccharide (LPS)-induced p65 translocation to the nucleus, and suppress LPS-induced NF- $\kappa \mathrm{B}$ activation in A549 lung cancer cells (Choi et al. 2009b). In addition, gallic acid inhibits the acetylation of p65 and LPS-induced serum levels of interleukin-6 in vivo.

Sanguinarine, an extract from several plants such as bloodroot (Sanguinaria canadensis) and in the root, stem, and leaves of the opium poppy, has been shown to induce conformational changes by interacting with chromatin (Selvi et al. 2009). Sanguinarine potently inhibited HAT activity in rat liver and cervical cancer cell lines, and this was associated with a dose-dependent decrease in $\mathrm{H} 3 / \mathrm{H} 4$ acetylation.

Resveratrol, a natural compound found in the skin of red grapes and a constituent of red wine, is believed to play a significant role in the reduction of cardiovascular events (Artaud-Wild et al. 1993; Gupta et al. 2011). Multiple studies have shown that resveratrol can activate sirtuin 1 (SIRT1), a histone deacetylase, and inhibit p300 (Howitz et al. 2003; Gracia-Sancho et al. 2010). Sirtuins, the class III HDACs, are widely distributed and have been shown to regulate a variety of physiopathologic processes, such as inflammation, cellular senescence and aging, cellular apoptosis and proliferation, differentiation, metabolism, stem cell pluri-potency, and cell cycle regulation. Polyphenols, including not only resveratrol but also quercetin and catechins, have been shown to activate SIRT1, the best characterized of the seven mammalian sirtuins, SIRT1-7 (Kaeberlein et al. 2005; Borra et al. 2005; de Boer et al. 2006).

Similar to EGCG, resveratrol showed weak inhibition of DNMT activity in nuclear extracts from MCF7 cells (Paluszczak et al. 2010). In these cells, resveratrol improved the action of adenosine analogues to inhibit methylation and to increase expression of the retinoic acid receptor beta 2 gene (Stefanska et al. 2010). In addition, resveratrol decreased the levels of the miR-155 by up-regulating miR-663, an miRNA targeting JunB and JunD (Tili et al. 2010a), and modulated expression levels of miRNA target genes, such as tumor suppressors and effectors of the transforming growth factor- $\beta$ signaling pathway, in SW480 cells (Tili et al. 2010b).

Anacardic acid, an active compound found in cashew nuts, has also been shown to be a specific HAT inhibitor (Balasubramanyam et al. 2003; Sun et al. 2006). Anacardic acid can inhibit p300, PCAF, and Tip60 HAT factors.

Garcinol, a highly cytotoxic polyisoprenylated benzophenone derived from garcinia fruit rinds, is also a potent inhibitor of different HATs, such as p300 and PCAF (Mai et al. 2006; Chandregowda et al. 2009; Balasubramanyam et al. 2004).

Plumbagin is another agent, derived from Plumbago rosea root extract, that has been found to potently inhibit HAT activity (Ravindra et al. 2009). Plumbagin derivatives without a hydroxyl group lost HAT inhibitory activity, indicating that the hydroxyl group is required for this activity.

Finally, genistein, one of the many phytoestrogens present in soybeans, has been recently studied as a demethylating agent. Genistein induced a dose-dependent inhibition of DNMT activity stronger than that of other soy isoflavones (biochanin A or diadzein) (Fang et al. 2005; Li et al. 2009). The continuously growing list of natural compounds (Table 1) that modulate epigenetic mechanisms shows the great interest in this exciting field and clinical trials performed with several of these compounds (Table 2) confirm their efficiency. 
Table 1 Common HDAC, HAT and DNMT modulators derived from natural sources

\begin{tabular}{|c|c|}
\hline Natural inhibitor & References \\
\hline \multicolumn{2}{|l|}{$\underline{H D A C}$} \\
\hline Allyl mercaptan & Nian et al. (2008) \\
\hline Amamistatin & Fennell and Miller (2007) \\
\hline Apicidin & Darkin-Rattray et al. (1996) \\
\hline Azumamide E & Maulucci et al. (2007) \\
\hline Caffeic acid & Waldecker et al. (2008) \\
\hline Chlamydocin & Brosch et al. (1995) \\
\hline Chlorogenic acid & Bora-Tatar et al. (2009) \\
\hline Cinnamic acid & Bora-Tatar et al. (2009) \\
\hline Coumaric/hydroxycinnamic acid & Waldecker et al. (2008) \\
\hline Curcumin & Bora-Tatar et al. (2009) \\
\hline Depudecin & Kwon et al. (1998) \\
\hline Diallyl disulfide & Lea et al. (1999) \\
\hline Equol & Hong et al. (2004) \\
\hline Flavone & Bontempo et al. (2007) \\
\hline Genistein & Kikuno et al. (2008) \\
\hline Histacin & Haggarty et al. (2003) \\
\hline Isothiocyanates & Ma et al. (2006) \\
\hline Largazole & Ying et al. (2008) \\
\hline Pomiferin & Son et al. (2007) \\
\hline Psammaplin & Pina et al. (2003) \\
\hline SAHA (Vorinostat) & Richon et al. (1998) \\
\hline S-allylmercaptocysteine & Lea et al. (2002) \\
\hline Sulforaphane & Myzak et al. (2004) \\
\hline Trapoxin & (Kijima et al. 1993) \\
\hline Ursolic acid & Chen et al. (2009) \\
\hline Zerumbone & Chung et al. (2008) \\
\hline \multicolumn{2}{|l|}{$H A T$} \\
\hline Allspice & Lee et al. (2007) \\
\hline Anarcardic acid & $\begin{array}{l}\text { Balasubramanyam et al. (2003), } \\
\text { Ghizzoni et al. (2010) }\end{array}$ \\
\hline EGCG & Choi et al. (2009a) \\
\hline Curcumin & $\begin{array}{l}\text { Balasubramanyam et al. (2004), } \\
\text { Marcu et al. (2006) }\end{array}$ \\
\hline Gallic acid & Choi et al. (2009b) \\
\hline Garcinol & Balasubramanyam et al. (2004) \\
\hline Quercetin & Ruiz et al. (2007) \\
\hline Sanguinarine & Selvi et al. (2009) \\
\hline Plumbagin & Ravindra et al. (2009) \\
\hline \multicolumn{2}{|l|}{ DNMT } \\
\hline Genistein & Day et al. (2002) \\
\hline EGCG & Fang et al. (2003) \\
\hline Psammaplins & Pina et al. (2003) \\
\hline Quercetin, fisetin, myricetin & Lee et al. (2005) \\
\hline Caffeic acid & Lee and Zhu (2006) \\
\hline Chlorogenic acid & Lee and Zhu (2006) \\
\hline Curcumin & Moiseeva et al. (2007) \\
\hline Parthenolide & Liu et al. (2009) \\
\hline Mahanine & Sheikh et al. (2010) \\
\hline
\end{tabular}

Nian et al. (2008)

Fennell and Miller (2007)

Darkin-Rattray et al. (1996)

Maulucci et al. (2007)

Waldecker et al. (2008)

Brosch et al. (1995)

a-Tatar et al. (2009)

Bora-Tatar et al. (2009)

Lea et al. (1999)

et al. (2004)

Bontempo et al. (2007)

Kikuno et al. (2008)

Haggarty et al. (2003)

Ma et al. (2006)

Ying et al. (2008)

Son et al. (2007)

Pina et al. (2003)

Richon et al. (1998)

Myzak et al. (2004)

ee et al. (2007)

Marcu et al. (2006)

Choi et al. (2009b)

Balasubramanyam et al. (2004)

Ruiz et al. (2007)

al. (2009)

Day et al. (2002)

al. (2003)

Lee and Zhu (2006)

Liu et al. (2009)
SAHA Suberoylanilide hydroxamic acid, $E G C G$ epigallocatechin gallate 
Table 2 Clinical studies with curcumin and other natural compounds

\begin{tabular}{|c|c|c|c|c|}
\hline Disease & Dose/frequency & Patients & End point modulation & References \\
\hline \multicolumn{5}{|l|}{ Curcumin } \\
\hline \multicolumn{5}{|l|}{ Safety trials } \\
\hline Phase 1 & $2,000 \mathrm{mg} /$ day & 10 & $\begin{array}{l}\text { Piperine enhanced bioavailability } \\
\text { by } 2,000 \%\end{array}$ & Shoba et al. (1998) \\
\hline Phase 1 & $500-12,000 \mathrm{mg} /$ day $\times 90$ days & 25 & $\begin{array}{l}\text { Histologic improvement of } \\
\text { precancerous lesions }\end{array}$ & Cheng et al. (2001) \\
\hline Phase 1 & $500-12,000 \mathrm{mg} /$ day & 24 & $\begin{array}{l}\text { Safe, well-tolerated even at } 12 \mathrm{~g} / \\
\text { day }\end{array}$ & Lao et al. (2006) \\
\hline \multicolumn{5}{|l|}{ Efficacy trials } \\
\hline Alzheimer's disease & $1 \mathrm{~g}$ once daily, $4 \mathrm{~g}$ once daily & 36 & - & Baum et al. (2008) \\
\hline Atherosclerosis & $10 \mathrm{mg} ; 2 \times /$ day $\times 28$ days & 12 & $\begin{array}{l}\text { Lowered LDL and ApoB, } \\
\text { increased HDL and ApoA }\end{array}$ & Ramirez Bosca et al. (2000) \\
\hline $\begin{array}{l}\text { Cadaveric renal } \\
\text { transplantation }\end{array}$ & $480 \mathrm{mg} ; 1-2 /$ day $\times 30$ days & 43 & $\begin{array}{l}\text { Improved renal function, reduced } \\
\text { neurotoxicity }\end{array}$ & Shoskes et al. (2005) \\
\hline Cardiovascular disease & $500 \mathrm{mg} /$ day $\times 7$ days & 10 & $\begin{array}{l}\text { Decreased serum lipid peroxidase } \\
(33 \%), \text { increased HDL } \\
\text { cholesterol }(29 \%), \text { decreased } \\
\text { total serum cholesterol }(12 \%)\end{array}$ & Soni and Kuttan (1992) \\
\hline Chronic anterior uveitis & $375 \mathrm{mg} ; 3 \times /$ day $\times 84$ days & 32 & $\begin{array}{l}86 \% \text { decrease in chronic anterior } \\
\text { uveitis }\end{array}$ & Lal et al. (1999) \\
\hline Crohn's disease & $\begin{array}{l}360 \mathrm{mg} \text {; } 3 / \text { day } \times 30 \text { days; } 4 \text { for } \\
60 \text { days }\end{array}$ & 5 & Improved symptoms & Holt et al. (2005) \\
\hline $\mathrm{CRC}$ & $36-180 \mathrm{mg} /$ day $\times 120$ days & 15 & Lowered GST & Sharma et al. (2001) \\
\hline $\mathrm{CRC}$ & $450-3,600 \mathrm{mg} /$ day $\times 120$ days & 15 & $\begin{array}{l}\text { Lowered inducible serum PGE2 } \\
\text { levels }\end{array}$ & Sharma et al. (2004) \\
\hline $\mathrm{CRC}$ & $450-3,600 \mathrm{mg} /$ day $\times 7$ days & 12 & Decreased M1G DNA adducts & Garcea et al. (2005) \\
\hline Colon cancer & $10 \mathrm{~g}(n=6)$ and $12 \mathrm{~g}(n=6)$ & 12 & Pharmacokinetics & Vareed et al. (2008) \\
\hline $\mathrm{CRC}, \mathrm{ACF}$ & $2 \mathrm{~g}$ or $4 \mathrm{~g} /$ day for 30 days & 44 & $\begin{array}{l}\text { A significant } 40 \% \text { reduction in } \\
\text { ACF number occurred with the } \\
4 \mathrm{~g} \text { dose }(P<0.005) \text {, whereas } \\
\text { ACF were not reduced in the } 2 \mathrm{~g} \\
\text { group }\end{array}$ & Carroll et al. (2011) \\
\hline External cancerous & $1 \%$ ointment for several months & 62 & $\begin{array}{l}\text { Reduction in smell in } 90 \% \\
\text { patients, reduction of itching in } \\
\text { all cases, dry lesions in } 70 \% \\
\text { patients, reduction in lesion size } \\
\text { and pain in } 10 \% \text { patients }\end{array}$ & Kuttan et al. (1987) \\
\hline FAP & $480 \mathrm{mg} ; 3 /$ day $\times 180$ days & 5 & $\begin{array}{l}\text { Decrease in the number of polyps } \\
(60.4 \%) \text {, decrease in the size of } \\
\text { polyps }(50.9 \%)\end{array}$ & Cruz-Correa et al. (2006) \\
\hline H. pylori infection & $300 \mathrm{mg} /$ day $\times 7$ days & 25 & $\begin{array}{l}\text { Significant improvement of } \\
\text { dyspeptic symptoms }\end{array}$ & Di Mario et al. (2007) \\
\hline HIV & $625 \mathrm{mg} ; 4 \times /$ day $\times 56$ days & 40 & Well tolerated & James (1996) \\
\hline IIOP & $375 \mathrm{mg} ; 3 \times /$ day $\times 180-660$ days & 8 & $\begin{array}{l}\text { Four patients recovered } \\
\text { completely; one patient showed } \\
\text { decrease in swelling, no } \\
\text { recurrence }\end{array}$ & Lal et al. (2000) \\
\hline Gall bladder function & $20 \mathrm{mg}$, single dose & 12 & $\begin{array}{l}\text { Decreased gall bladder volume } \\
(29 \%)\end{array}$ & Rasyid and Lelo (1999) \\
\hline Gall bladder function & 20-80 mg, single dose & 12 & $\begin{array}{l}\text { Decreased gall bladder volume } \\
(72 \%)\end{array}$ & Rasyid et al. (2002) \\
\hline $\mathrm{ICF}$ & - & 1,010 & Better MMSE score & $\mathrm{Ng}$ et al. (2006) \\
\hline IBS & $72-144 \mathrm{mg} /$ day $\times 56$ days & 207 & Reduced symptoms & Bundy et al. (2004) \\
\hline Liver metastasis & $450-3,600 \mathrm{mg} /$ day $\times 7$ day & 12 & Low bioavailability & Garcea et al. (2004) \\
\hline
\end{tabular}


Table 2 continued

\begin{tabular}{|c|c|c|c|c|}
\hline Disease & Dose/frequency & Patients & End point modulation & References \\
\hline Pancreatic cancer & $8 \mathrm{~g}$ by mouth daily every 2 months & 25 & $\begin{array}{l}\text { Oral curcumin is well tolerated } \\
\text { and, despite its limited } \\
\text { absorption, has biological } \\
\text { activity in some patients with } \\
\text { pancreatic cancer }\end{array}$ & Dhillon et al. (2008) \\
\hline Pancreatic cancer & $8 \mathrm{~g}$ & 21 & $\begin{array}{l}\text { Safe and feasible in patients with } \\
\text { pancreatic cancer }\end{array}$ & Kanai et al. (2010) \\
\hline Postoperative inflammation & $400 \mathrm{mg} ; 3 \times /$ day $\times 5$ days & 46 & Decrease in inflammation & Satoskar et al. (1986) \\
\hline PIN & - & 24 & - & Rafailov et al. (2007) \\
\hline Psoriasis & $1 \%$ curcumin gel & 40 & $\begin{array}{l}\text { Decreased } \mathrm{PhK} 2 \text {, TRR3, } \\
\text { parakeratosis, and density of } \\
\text { epidermal CD }{ }^{+} \mathrm{T} \text { cells }\end{array}$ & Heng et al. (2000) \\
\hline Psoriasis & $4.5 \mathrm{~g} / \mathrm{d}$ & 18 & The response rate was low & Kurd et al. (2008) \\
\hline Rheumatoid arthritis & $1,200 \mathrm{mg} /$ day $\times 14$ days & 18 & Improved symptoms & Deodhar et al. (1980) \\
\hline Tropical pancreatitis & $500 \mathrm{mg} /$ day $\times 42$ days & 20 & $\begin{array}{l}\text { Reduction in the erythrocyte MDA } \\
\text { levels, increased erythrocyte } \\
\text { GSH levels }\end{array}$ & Durgaprasad and Pai (2005) \\
\hline Ulcerative proctitis & $550 \mathrm{mg} ; 2-3 /$ day $\times 60$ days & 5 & Improved symptoms & Holt et al. (2005) \\
\hline Ulcerative colitis & $2,000 \mathrm{mg} /$ day $\times 180$ days & 89 & $\begin{array}{l}\text { Low recurrence; improved } \\
\text { symptoms }\end{array}$ & Hanai et al. (2006) \\
\hline \multicolumn{5}{|l|}{$E G C G$} \\
\hline \multicolumn{5}{|l|}{ Safety trials } \\
\hline Phase 1 & $200,400,600$, and $800 \mathrm{mg}$ & 20 & Systemic availability & Chow et al. (2001) \\
\hline \multicolumn{5}{|l|}{ Efficacy trials } \\
\hline OHT and OAG & $200 \mathrm{mg} /$ day for 3 months & 36 & $\begin{array}{l}\text { Influenced inner retinal function in } \\
\text { eyes with early to moderately } \\
\text { advanced glaucomatous }\end{array}$ & Falsini et al. (2009) \\
\hline EE and fat oxidation & Catechins: $493.8-684 \mathrm{mg}$ & 15 & $\begin{array}{l}\text { Small acute effects on EE and fat } \\
\text { oxidation }\end{array}$ & Gregersen et al. (2009) \\
\hline Influenza infection & $\begin{array}{l}\text { Catechins: } 200 \mu \mathrm{g} / \mathrm{mL} 3 / \text { day for } \\
3 \text { months }\end{array}$ & 124 & $\begin{array}{l}\text { Influenza infection was } \\
\text { significantly lowered }\end{array}$ & Yamada et al. (2006) \\
\hline Inhalation of MRSA &  & 72 & $\begin{array}{l}\text { Reduced the MRSA count in } \\
\text { sputum }\end{array}$ & Yamada et al. (2006) \\
\hline \multicolumn{5}{|l|}{ Resveratrol } \\
\hline \multicolumn{5}{|l|}{ Safety trial } \\
\hline Pharmaco-kinetics & $0.5,1,2.5$, or $5 \mathrm{~g}$ daily for 29 days & 40 & $\begin{array}{l}2.5 \text { and } 5 \mathrm{~g} \text { doses caused mild to } \\
\text { moderate gastrointestinal } \\
\text { symptoms }\end{array}$ & Brown et al. (2010) \\
\hline Phase 1 & $0.5,1,2.5$, or $5 \mathrm{~g}$ & 10 & $\begin{array}{l}\text { High systemic levels of resveratrol } \\
\text { conjugate metabolites }\end{array}$ & Boocock et al. (2007) \\
\hline \multicolumn{5}{|l|}{ Efficacy trials } \\
\hline Cerebral blood flow & 250 and $500 \mathrm{mg}$ & 22 & $\begin{array}{l}\text { Modulated cerebral blood flow } \\
\text { variables }\end{array}$ & Kennedy et al. (2010) \\
\hline $\begin{array}{l}\text { Drug- and carcinogen- } \\
\text { metabolizing enzymes }\end{array}$ & $\begin{array}{l}1 \mathrm{~g} \text { of resveratrol once daily for } \\
4 \text { weeks }\end{array}$ & 42 & $\begin{array}{l}\text { Modulated enzyme systems } \\
\text { involved in carcinogen activation } \\
\text { and detoxification }\end{array}$ & Chow et al. (2010) \\
\hline $\mathrm{CRC}$ & 8 daily doses of 0.5 or $1 \mathrm{~g}$ & 20 & $\begin{array}{l}\text { Reduced tumor cell proliferation } \\
\text { by } 5 \%\end{array}$ & Patel et al. (2010) \\
\hline \multicolumn{5}{|l|}{ Genistein } \\
\hline \multicolumn{5}{|l|}{ Safety trial } \\
\hline Phase 1 & $600 \mathrm{mg} /$ day for 84 days & 18 & Safe and well tolerated & Pop et al. (2008) \\
\hline Pharmaco-kinetics & $2,4,8$, or $16 \mathrm{mg} / \mathrm{kg}$ & 24 & Minimal clinical toxicity & Bloedon et al. (2002) \\
\hline Efficacy trials & & & & \\
\hline
\end{tabular}


Table 2 continued

\begin{tabular}{|c|c|c|c|c|}
\hline Disease & Dose/frequency & Patients & End point modulation & References \\
\hline Endometrial hyperplasia & $54 \mathrm{mg} /$ day for 6 months & 56 & $\begin{array}{l}\text { Useful for the management of } \\
\text { endometrial hyperplasia }\end{array}$ & Bitto et al. (2010) \\
\hline Prostate cancer & $450 \mathrm{mg}$ daily for 6 months & 53 & Did not lower PSA levels & deVere White et al. (2010) \\
\hline $\mathrm{CV}$ risk & $54 \mathrm{mg} / \mathrm{day}$ for 24 months & 198 & $\begin{array}{l}\text { Favorable effects on both glycemic } \\
\text { control and some cardiovascular } \\
\text { risk markers }\end{array}$ & Atteritano et al. (2007) \\
\hline Coronary heart disease & $71 \mathrm{mg}$ & 33 & Neither harmful nor beneficial & Webb et al. (2008) \\
\hline Bone metabolism & - & 208 & Protective against bone loss & $\begin{array}{l}\text { Kritz-Silverstein and } \\
\text { Goodman-Gruen (2002) }\end{array}$ \\
\hline Asthma & - & 1,033 & Better lung function & Smith et al. (2004) \\
\hline
\end{tabular}

$A C F$ Aberrant crypt foci, $C R C$ colorectal cancer, $C V$ cardiovascular, $E E$ energy expenditure, $E G C G$ epigallocatechin, $F A P$ familial adenomatous polyposis, $G S H$ glutathione, $G S T$ glutathione S-transferase, $H D L$ high-density lipoprotein, $H I V$ human immunodeficiency virus, $I B S$ irritable bowel syndrome, $I C F$ improved cognitive function, IIOP idiopathic inflammatory orbital pseudotumors, $L D L$ low-density lipoprotein, $M D A$ malondialdehyde, MMSE mini-mental state examination, MRSA methicillin-resistant Staphylococcus aureus, $O A G$ open-angle glaucoma, $O H T$ ocular hyper-damage tension, PGE2 prostaglandin E2, PhK2 phosphorylase kinase 2, PIN prostatic intraepithelial neoplasia, PSA prostatespecific antigen, TRR3 transferrin receptor 3

\section{Conclusion}

Experimental evidence accumulated in the recent years clearly supports the idea that dietary nutraceuticals such as curcumin have great potential as epigenetic agents. Unlike genetic changes, epigenetic changes can be modified by the environment, diet, or pharmacological intervention. This characteristic has increased enthusiasm for developing therapeutic strategies by targeting the various epigenetic factors, such as HDAC, HAT, DNMTs, and miRNAs, by dietary polyphenols such as curcumin (Fig. 2). Further investigation of phytochemicals as epigenetic agents is, however, urgently needed to fully explore the potential of these nutraceuticals in the treatment of cancer and other diseases.

Acknowledgments We thank Virginia Mohlere for carefully editing this article. This work was supported by MD Anderson's Cancer Center Support Grant from the National Institutes of Health (NIH CA16672), a program project grant from the National Institutes of Health (NIH CA-124787-01A2), and a grant from the Center for Targeted Therapy at The University of Texas MD Anderson Cancer Center, where Dr. Aggarwal is the Ransom Horne, Jr., Professor of Cancer Research. Simone Reuter was supported by a grant from the Fonds National de la Recherche Luxembourg (PDR-08-017).

\section{References}

Aggarwal BB (2004) Nuclear factor-kappaB: the enemy within. Cancer Cell 6:203-208

Aggarwal BB, Sung B (2009) Pharmacological basis for the role of curcumin in chronic diseases: an age-old spice with modern targets. Trends Pharmacol Sci 30:85-94

Aggarwal BB, Kumar A, Bharti AC (2003) Anticancer potential of curcumin: preclinical and clinical studies. Anticancer Res 23:363-398
Aggarwal BB, Shishodia S, Takada Y, Banerjee S, Newman RA, Bueso-Ramos CE et al (2005) Curcumin suppresses the paclitaxel-induced nuclear factor-kappaB pathway in breast cancer cells and inhibits lung metastasis of human breast cancer in nude mice. Clin Cancer Res 11:7490-7498

Aggarwal BB, Kunnumakkara AB, Harikumar KB, Gupta SR, Tharakan ST, Koca C et al (2009) Signal transducer and activator of transcription-3, inflammation, and cancer: how intimate is the relationship? Ann N Y Acad Sci 1171:59-76

Ali S, Ahmad A, Banerjee S, Padhye S, Dominiak K, Schaffert JM et al (2010) Gemcitabine sensitivity can be induced in pancreatic cancer cells through modulation of miR-200 and miR-21 expression by curcumin or its analogue CDF. Cancer Res 70:3606-3617

Araujo CC, Leon LL (2001) Biological activities of Curcuma longa L. Mem Inst Oswaldo Cruz 96:723-728

Artaud-Wild SM, Connor SL, Sexton G, Connor WE (1993) Differences in coronary mortality can be explained by differences in cholesterol and saturated fat intakes in 40 countries but not in France and Finland. A paradox. Circulation 88:2771-2779

Atteritano M, Marini H, Minutoli L, Polito F, Bitto A, Altavilla D et al (2007) Effects of the phytoestrogen genistein on some predictors of cardiovascular risk in osteopenic, postmenopausal women: a two-year randomized, double-blind, placebo-controlled study. J Clin Endocrinol Metab 92:3068-3075

Balasubramanyam K, Swaminathan V, Ranganathan A, Kundu TK (2003) Small molecule modulators of histone acetyltransferase p300. J Biol Chem 278:19134-19140

Balasubramanyam K, Varier RA, Altaf M, Swaminathan V, Siddappa NB, Ranga U et al (2004a) Curcumin, a novel p300/CREBbinding protein-specific inhibitor of acetyltransferase, represses the acetylation of histone/nonhistone proteins and histone acetyltransferase-dependent chromatin transcription. J Biol Chem 279:51163-51171

Balasubramanyam K, Altaf M, Varier RA, Swaminathan V, Ravindran A, Sadhale PP et al (2004b) Polyisoprenylated benzophenone, garcinol, a natural histone acetyltransferase inhibitor, represses chromatin transcription and alters global gene expression. J Biol Chem 279:33716-33726

Bartel DP (2004) MicroRNAs: genomics, biogenesis, mechanism, and function. Cell 116:281-297 
Baum L, Lam CW, Cheung SK, Kwok T, Lui V, Tsoh J et al (2008) Six-month randomized, placebo-controlled, double-blind, pilot clinical trial of curcumin in patients with Alzheimer disease. J Clin Psychopharmacol 28:110-113

Baur JA (2010) Resveratrol, sirtuins, and the promise of a DR mimetic. Mech Ageing Dev 131:261-269

Bayet-Robert M, Kwiatkowski F, Leheurteur M, Gachon F, Planchat E, Abrial C et al (2010) Phase I dose escalation trial of docetaxel plus curcumin in patients with advanced and metastatic breast cancer. Cancer Biol Ther 9:8-14

Bentwich I, Avniel A, Karov Y, Aharonov R, Gilad S, Barad O et al (2005) Identification of hundreds of conserved and nonconserved human microRNAs. Nat Genet 37:766-770

Bharti AC, Donato N, Aggarwal BB (2003) Curcumin (diferuloylmethane) inhibits constitutive and IL-6-inducible STAT3 phosphorylation in human multiple myeloma cells. J Immunol 171:3863-3871

Bharti AC, Shishodia S, Reuben JM, Weber D, Alexanian R, RajVadhan S et al (2004) Nuclear factor-kappaB and STAT3 are constitutively active in CD138 + cells derived from multiple myeloma patients, and suppression of these transcription factors leads to apoptosis. Blood 103:3175-3184

Bierhaus A, Zhang Y, Quehenberger P, Luther T, Haase M, Muller M et al (1997) The dietary pigment curcumin reduces endothelial tissue factor gene expression by inhibiting binding of AP-1 to the DNA and activation of NF-kappa B. Thromb Haemost 77:772-782

Bischoff G, Hoffmann S (2002) DNA-binding of drugs used in medicinal therapies. Curr Med Chem 9:312-348

Bitto A, Granese R, Triolo O, Villari D, Maisano D, Giordano D et al (2010) Genistein aglycone: a new therapeutic approach to reduce endometrial hyperplasia. Phytomedicine 17:844-850

Bloedon LT, Jeffcoat AR, Lopaczynski W, Schell MJ, Black TM, Dix KJ et al (2002) Safety and pharmacokinetics of purified soy isoflavones: single-dose administration to postmenopausal women. Am J Clin Nutr 76:1126-1137

Bontempo P, Mita L, Miceli M, Doto A, Nebbioso A, De Bellis F et al (2007) Feijoa sellowiana derived natural Flavone exerts anticancer action displaying HDAC inhibitory activities. Int $\mathrm{J}$ Biochem Cell Biol 39:1902-1914

Boocock DJ, Faust GE, Patel KR, Schinas AM, Brown VA, Ducharme MP et al (2007) Phase I dose escalation pharmacokinetic study in healthy volunteers of resveratrol, a potential cancer chemopreventive agent. Cancer Epidemiol Biomarkers Prev 16:1246-1252

Bora-Tatar G, Dayangac-Erden D, Demir AS, Dalkara S, Yelekci K, Erdem-Yurter H (2009) Molecular modifications on carboxylic acid derivatives as potent histone deacetylase inhibitors: Activity and docking studies. Bioorg Med Chem 17:5219-5228

Borra MT, Smith BC, Denu JM (2005) Mechanism of human SIRT1 activation by resveratrol. J Biol Chem 280:17187-17195

Brosch G, Ransom R, Lechner T, Walton JD, Loidl P (1995) Inhibition of maize histone deacetylases by HC toxin, the hostselective toxin of Cochliobolus carbonum. Plant Cell 7:1941-1950

Brown VA, Patel KR, Viskaduraki M, Crowell JA, Perloff M, Booth TD et al (2010) Repeat dose study of the cancer chemopreventive agent resveratrol in healthy volunteers: safety, pharmacokinetics, and effect on the insulin-like growth factor axis. Cancer Res 70:9003-9011

Bundy R, Walker AF, Middleton RW, Booth J (2004) Turmeric extract may improve irritable bowel syndrome symptomology in otherwise healthy adults: a pilot study. J Altern Complement Med 10:1015-1018

Carroll RE, Benya RV, Turgeon DK, Vareed S, Neuman M, Rodriguez L et al (2011) Phase IIa Clinical Trial of Curcumin for the Prevention of Colorectal Neoplasia. Cancer Prev Res (Phila) 4:354-364

Chandregowda V, Kush A, Reddy GC (2009) Synthesis of benzamide derivatives of anacardic acid and their cytotoxic activity. Eur J Med Chem 44:2711-2719

Chauhan DP (2002) Chemotherapeutic potential of curcumin for colorectal cancer. Curr Pharm Des 8:1695-1706

Chen YR, Tan TH (1998) Inhibition of the c-Jun N-terminal kinase (JNK) signaling pathway by curcumin. Oncogene 17:173-178

Chen L, Fischle W, Verdin E, Greene WC (2001) Duration of nuclear NF-kappaB action regulated by reversible acetylation. Science 293:1653-1657

Chen Y, Shu W, Chen W, Wu Q, Liu H, Cui G (2007) Curcumin, both histone deacetylase and p300/CBP-specific inhibitor, represses the activity of nuclear factor kappa B and Notch 1 in Raji cells. Basic Clin Pharmacol Toxicol 101:427-433

Chen IH, Lu MC, Du YC, Yen MH, Wu CC, Chen YH et al (2009) Cytotoxic triterpenoids from the stems of Microtropis japonica. J Nat Prod 72:1231-1236

Cheng AL, Hsu CH, Lin JK, Hsu MM, Ho YF, Shen TS et al (2001) Phase I clinical trial of curcumin, a chemopreventive agent, in patients with high-risk or pre-malignant lesions. Anticancer Res 21:2895-2900

Choi KC, Jung MG, Lee YH, Yoon JC, Kwon SH, Kang HB et al (2009a) Epigallocatechin-3-gallate, a histone acetyltransferase inhibitor, inhibits EBV-induced B lymphocyte transformation via suppression of RelA acetylation. Cancer Res 69:583-592

Choi KC, Lee YH, Jung MG, Kwon SH, Kim MJ, Jun WJ et al (2009b) Gallic acid suppresses lipopolysaccharide-induced nuclear factor-kappaB signaling by preventing RelA acetylation in A549 lung cancer cells. Mol Cancer Res 7:2011-2021

Chow HH, Cai Y, Alberts DS, Hakim I, Dorr R, Shahi F et al (2001) Phase I pharmacokinetic study of tea polyphenols following single-dose administration of epigallocatechin gallate and polyphenon E. Cancer Epidemiol Biomarkers Prev 10:53-58

Chow HH, Garland LL, Hsu CH, Vining DR, Chew WM, Miller JA et al (2010) Resveratrol modulates drug- and carcinogenmetabolizing enzymes in a healthy volunteer study. Cancer Prev Res (Phila) 3:1168-1175

Chung IM, Kim MY, Park WH, Moon HI (2008) Histone deacetylase inhibitors from the rhizomes of Zingiber zerumbet. Pharmazie 63:774-776

Croce CM (2009) Causes and consequences of microRNA dysregulation in cancer. Nat Rev Genet 10:704-714

Cruz-Correa M, Shoskes DA, Sanchez P, Zhao R, Hylind LM, Wexner SD et al (2006) Combination treatment with curcumin and quercetin of adenomas in familial adenomatous polyposis. Clin Gastroenterol Hepatol 4:1035-1038

Darkin-Rattray SJ, Gurnett AM, Myers RW, Dulski PM, Crumley TM, Allocco JJ et al (1996) Apicidin: a novel antiprotozoal agent that inhibits parasite histone deacetylase. Proc Natl Acad Sci U S A 93:13143-13147

Das PM, Singal R (2004) DNA methylation and cancer. J Clin Oncol 22:4632-4642

Davie JR (2003) Inhibition of histone deacetylase activity by butyrate. J Nutr 133:2485S-2493S

Davis CD, Ross SA (2007) Dietary components impact histone modifications and cancer risk. Nutr Rev 65:88-94

Davis CD, Ross SA (2008) Evidence for dietary regulation of microRNA expression in cancer cells. Nutr Rev 66:477-482

Day JK, Bauer AM, DesBordes C, Zhuang Y, Kim BE, Newton LG et al (2002) Genistein alters methylation patterns in mice. J Nutr 132:2419S-2423S

de Boer VC, de Goffau MC, Arts IC, Hollman PC, Keijer J (2006) SIRT1 stimulation by polyphenols is affected by their stability and metabolism. Mech Ageing Dev 127:618-627 
Delage B, Dashwood RH (2008) Dietary manipulation of histone structure and function. Annu Rev Nutr 28:347-366

Deodhar SD, Sethi R, Srimal RC (1980) Preliminary study on antirheumatic activity of curcumin (diferuloyl methane). Indian J Med Res 71:632-634

Devasagayam TP, Tilak JC, Boloor KK, Sane KS, Ghaskadbi SS, Lele RD (2004) Free radicals and antioxidants in human health: current status and future prospects. J Assoc Physicians India 52:794-804

deVere White RW, Tsodikov A, Stapp EC, Soares SE, Fujii H, Hackman RM (2010) Effects of a high dose, aglycone-rich soy extract on prostate-specific antigen and serum isoflavone concentrations in men with localized prostate cancer. Nutr Cancer 62:1036-1043

Dhillon N, Aggarwal BB, Newman RA, Wolff RA, Kunnumakkara AB, Abbruzzese JL et al (2008) Phase II trial of curcumin in patients with advanced pancreatic cancer. Clin Cancer Res 14:4491-4499

Di Mario F, Cavallaro LG, Nouvenne A, Stefani N, Cavestro GM, Iori V et al (2007) A curcumin-based 1-week triple therapy for eradication of Helicobacter pylori infection: something to learn from failure? Helicobacter 12:238-243

Durgaprasad S, Pai CG (2005) Vasanthkumar, Alvres JF, Namitha S. A pilot study of the antioxidant effect of curcumin in tropical pancreatitis. Indian J Med Res 122:315-318

Ehrlich M (2009) DNA hypomethylation in cancer cells. Epigenomics $1: 239-259$

Esteller M (2007) Cancer epigenomics: DNA methylomes and histone-modification maps. Nat Rev Genet 8:286-298

Fairlamb AH (2003) Chemotherapy of human African trypanosomiasis: current and future prospects. Trends Parasitol 19:488-494

Falsini B, Marangoni D, Salgarello T, Stifano G, Montrone L, Di Landro $S$ et al (2009) Effect of epigallocatechin-gallate on inner retinal function in ocular hypertension and glaucoma: a shortterm study by pattern electroretinogram. Graefes Arch Clin Exp Ophthalmol 247:1223-1233

Fang MZ, Wang Y, Ai N, Hou Z, Sun Y, Lu H et al (2003) Tea polyphenol (-)-epigallocatechin-3-gallate inhibits DNA methyltransferase and reactivates methylation-silenced genes in cancer cell lines. Cancer Res 63:7563-7570

Fang MZ, Chen D, Sun Y, Jin Z, Christman JK, Yang CS (2005) Reversal of hypermethylation and reactivation of p16INK4a, RARbeta, and MGMT genes by genistein and other isoflavones from soy. Clin Cancer Res 11:7033-7041

Fennell KA, Miller MJ (2007) Syntheses of amamistatin fragments and determination of their HDAC and antitumor activity. Org Lett 9:1683-1685

Garcea G, Jones DJ, Singh R, Dennison AR, Farmer PB, Sharma RA et al (2004) Detection of curcumin and its metabolites in hepatic tissue and portal blood of patients following oral administration. Br J Cancer 90:1011-1015

Garcea G, Berry DP, Jones DJ, Singh R, Dennison AR, Farmer PB et al (2005) Consumption of the putative chemopreventive agent curcumin by cancer patients: assessment of curcumin levels in the colorectum and their pharmacodynamic consequences. Cancer Epidemiol Biomarkers Prev 14:120-125

Ghizzoni M, Boltjes A, Graaf C, Haisma HJ, Dekker FJ (2010) Improved inhibition of the histone acetyltransferase PCAF by an anacardic acid derivative. Bioorg Med Chem 18:5826-5834

Gibbons RJ (2005) Histone modifying and chromatin remodelling enzymes in cancer and dysplastic syndromes. Hum Mol Genet 14(1):R85-R92

Glozak MA, Sengupta N, Zhang X, Seto E (2005) Acetylation and deacetylation of non-histone proteins. Gene 363:15-23

Gracia-Sancho J, Villarreal G Jr, Zhang Y, Garcia-Cardena G (2010) Activation of SIRT1 by resveratrol induces KLF2 expression conferring an endothelial vasoprotective phenotype. Cardiovasc Res 85:514-519

Gregersen NT, Bitz C, Krog-Mikkelsen I, Hels O, Kovacs EM, Rycroft JA et al (2009) Effect of moderate intakes of different tea catechins and caffeine on acute measures of energy metabolism under sedentary conditions. $\mathrm{Br} \mathrm{J}$ Nutr 102:1187-1194

Gupta SC, Sundaram C, Reuter S, Aggarwal BB (2010a) Inhibiting NF-kappaB activation by small molecules as a therapeutic strategy. Biochim Biophys Acta 1799:775-787

Gupta SC, Kim JH, Prasad S, Aggarwal BB (2010b) Regulation of survival, proliferation, invasion, angiogenesis, and metastasis of tumor cells through modulation of inflammatory pathways by nutraceuticals. Cancer Metastasis Rev 29:405-434

Gupta SC, Kannappan R, Reuter S, Kim JH, Aggarwal BB (2011) Chemosensitization of tumors by resveratrol. Ann N Y Acad Sci 1215:150-160

Haggarty SJ, Koeller KM, Wong JC, Butcher RA, Schreiber SL (2003) Multidimensional chemical genetic analysis of diversityoriented synthesis-derived deacetylase inhibitors using cellbased assays. Chem Biol 10:383-396

Hanai H, Iida T, Takeuchi K, Watanabe F, Maruyama Y, Andoh A et al (2006) Curcumin maintenance therapy for ulcerative colitis: randomized, multicenter, double-blind, placebo-controlled trial. Clin Gastroenterol Hepatol 4:1502-1506

Heijmans BT, Tobi EW, Stein AD, Putter H, Blauw GJ, Susser ES et al (2008) Persistent epigenetic differences associated with prenatal exposure to famine in humans. Proc Natl Acad Sci U S A $105: 17046-17049$

Heng MC, Song MK, Harker J, Heng MK (2000) Drug-induced suppression of phosphorylase kinase activity correlates with resolution of psoriasis as assessed by clinical, histological and immunohistochemical parameters. Br J Dermatol 143:937-949

Herman JG, Baylin SB (2003) Gene silencing in cancer in association with promoter hypermethylation. N Engl J Med 349:2042-2054

Holt PR, Katz S, Kirshoff R (2005) Curcumin therapy in inflammatory bowel disease: a pilot study. Dig Dis Sci 50:2191-2193

Hong T, Nakagawa T, Pan W, Kim MY, Kraus WL, Ikehara T et al (2004) Isoflavones stimulate estrogen receptor-mediated core histone acetylation. Biochem Biophys Res Commun 317:259-264

Howitz KT, Bitterman KJ, Cohen HY, Lamming DW, Lavu S, Wood JG et al (2003) Small molecule activators of sirtuins extend Saccharomyces cerevisiae lifespan. Nature 425:191-196

Huang MT, Lysz T, Ferraro T, Abidi TF, Laskin JD, Conney AH (1991) Inhibitory effects of curcumin on in vitro lipoxygenase and cyclooxygenase activities in mouse epidermis. Cancer Res 51:813-819

Itokawa H, Shi Q, Akiyama T, Morris-Natschke SL, Lee KH (2008) Recent advances in the investigation of curcuminoids. Chin Med 3:11

James JS (1996) Curcumin: clinical trial finds no antiviral effect. AIDS Treat News 242:1-2

Jobin C, Bradham CA, Russo MP, Juma B, Narula AS, Brenner DA et al (1999) Curcumin blocks cytokine-mediated NF-kappa B activation and proinflammatory gene expression by inhibiting inhibitory factor I-kappa B kinase activity. J Immunol 163:3474-3483

Kaeberlein M, McDonagh T, Heltweg B, Hixon J, Westman EA, Caldwell SD et al (2005) Substrate-specific activation of sirtuins by resveratrol. J Biol Chem 280:17038-17045

Kanai M, Yoshimura K, Asada M, Imaizumi A, Suzuki C, Matsumoto $S$ et al (2010) A phase I/II study of gemcitabine-based chemotherapy plus curcumin for patients with gemcitabineresistant pancreatic cancer. Cancer Chemother Pharmacol

Kang SK, Cha SH, Jeon HG (2006) Curcumin-induced histone hypoacetylation enhances caspase-3-dependent glioma cell death 
and neurogenesis of neural progenitor cells. Stem Cells Dev $15: 165-174$

Karin M, Liu Z, Zandi E (1997) AP-1 function and regulation. Curr Opin Cell Biol 9:240-246

Kennedy DO, Wightman EL, Reay JL, Lietz G, Okello EJ, Wilde A et al (2010) Effects of resveratrol on cerebral blood flow variables and cognitive performance in humans: a double-blind, placebo-controlled, crossover investigation. Am J Clin Nutr 91:1590-1607

Kijima M, Yoshida M, Sugita K, Horinouchi S, Beppu T (1993) Trapoxin, an antitumor cyclic tetrapeptide, is an irreversible inhibitor of mammalian histone deacetylase. J Biol Chem 268:22429-22435

Kikuno N, Shiina H, Urakami S, Kawamoto K, Hirata H, Tanaka Y et al (2008) Genistein mediated histone acetylation and demethylation activates tumor suppressor genes in prostate cancer cells. Int J Cancer 123:552-560

Korpal M, Kang Y (2008) The emerging role of miR-200 family of microRNAs in epithelial-mesenchymal transition and cancer metastasis. RNA Biol 5:115-119

Kritz-Silverstein D, Goodman-Gruen DL (2002) Usual dietary isoflavone intake, bone mineral density, and bone metabolism in postmenopausal women. J Womens Health Gend Based Med 11:69-78

Kruh J (1982) Effects of sodium butyrate, a new pharmacological agent, on cells in culture. Mol Cell Biochem 42:65-82

Kurd SK, Smith N, VanVoorhees A, Troxel AB, Badmaev V, Seykora JT et al (2008) Oral curcumin in the treatment of moderate to severe psoriasis vulgaris: A prospective clinical trial. J Am Acad Dermatol 58:625-631

Kuttan R, Sudheeran PC, Josph CD (1987) Turmeric and curcumin as topical agents in cancer therapy. Tumori 73:29-31

Kwon HJ, Owa T, Hassig CA, Shimada J, Schreiber SL (1998) Depudecin induces morphological reversion of transformed fibroblasts via the inhibition of histone deacetylase. Proc Natl Acad Sci U S A 95:3356-3361

Lal B, Kapoor AK, Asthana OP, Agrawal PK, Prasad R, Kumar P et al (1999) Efficacy of curcumin in the management of chronic anterior uveitis. Phytother Res 13:318-322

Lal B, Kapoor AK, Agrawal PK, Asthana OP, Srimal RC (2000) Role of curcumin in idiopathic inflammatory orbital pseudotumours. Phytother Res 14:443-447

Lao CD, Ruffin MTt, Normolle D, Heath DD, Murray SI, Bailey JM et al (2006) Dose escalation of a curcuminoid formulation. BMC Complement Altern Med 6:10

Lea MA, Randolph VM, Patel M (1999) Increased acetylation of histones induced by diallyl disulfide and structurally related molecules. Int J Oncol 15:347-352

Lea MA, Rasheed M, Randolph VM, Khan F, Shareef A, desBordes C (2002) Induction of histone acetylation and inhibition of growth of mouse erythroleukemia cells by S-allylmercaptocysteine. Nutr Cancer 43:90-102

Lee KK, Workman JL (2007) Histone acetyltransferase complexes: one size doesn't fit all. Nat Rev Mol Cell Biol 8:284-295

Lee WJ, Zhu BT (2006) Inhibition of DNA methylation by caffeic acid and chlorogenic acid, two common catechol-containing coffee polyphenols. Carcinogenesis 27:269-277

Lee WJ, Shim JY, Zhu BT (2005) Mechanisms for the inhibition of DNA methyltransferases by tea catechins and bioflavonoids. Mol Pharmacol 68:1018-1030

Lee YH, Hong SW, Jun W, Cho HY, Kim HC, Jung MG et al (2007) Anti-histone acetyltransferase activity from allspice extracts inhibits androgen receptor-dependent prostate cancer cell growth. Biosci Biotechnol Biochem 71:2712-2719
Li Y, Liu L, Andrews LG, Tollefsbol TO (2009) Genistein depletes telomerase activity through cross-talk between genetic and epigenetic mechanisms. Int J Cancer 125:286-296

Li Y, Kong D, Wang Z, Sarkar FH (2010) Regulation of microRNAs by natural agents: an emerging field in chemoprevention and chemotherapy research. Pharm Res 27:1027-1041

Link A, Balaguer F, Goel A (2010) Cancer chemoprevention by dietary polyphenols: Promising role for epigenetics. Biochem Pharmacol 80:1771-1792

Liu HL, Chen Y, Cui GH, Zhou JF (2005) Curcumin, a potent anti-tumor reagent, is a novel histone deacetylase inhibitor regulating B-NHL cell line Raji proliferation. Acta Pharmacol Sin 26:603-609

Liu Z, Xie Z, Jones W, Pavlovicz RE, Liu S, Yu J et al (2009a) Curcumin is a potent DNA hypomethylation agent. Bioorg Med Chem Lett 19:706-709

Liu Z, Liu S, Xie Z, Pavlovicz RE, Wu J, Chen P et al (2009b) Modulation of DNA methylation by a sesquiterpene lactone parthenolide. J Pharmacol Exp Ther 329:505-514

Ma X, Fang Y, Beklemisheva A, Dai W, Feng J, Ahmed T et al (2006) Phenylhexyl isothiocyanate inhibits histone deacetylases and remodels chromatins to induce growth arrest in human leukemia cells. Int J Oncol 28:1287-1293

Mackenzie GG, Queisser N, Wolfson ML, Fraga CG, Adamo AM, Oteiza PI (2008) Curcumin induces cell-arrest and apoptosis in association with the inhibition of constitutively active NFkappaB and STAT3 pathways in Hodgkin's lymphoma cells. Int J Cancer 123:56-65

Mai A, Rotili D, Tarantino D, Ornaghi P, Tosi F, Vicidomini C et al (2006) Small-molecule inhibitors of histone acetyltransferase activity: identification and biological properties. J Med Chem 49:6897-6907

Marcu MG, Jung YJ, Lee S, Chung EJ, Lee MJ, Trepel J et al (2006) Curcumin is an inhibitor of p300 histone acetylatransferase. Med Chem 2:169-174

Maulucci N, Chini MG, Micco SD, Izzo I, Cafaro E, Russo A et al (2007) Molecular insights into azumamide e histone deacetylases inhibitory activity. J Am Chem Soc 129:3007-3012

Medina-Franco JL, Lopez-Vallejo F, Kuck D, Lyko F (2010) Natural products as DNA methyltransferase inhibitors: a computer-aided discovery approach. Mol Divers

Meja KK, Rajendrasozhan S, Adenuga D, Biswas SK, Sundar IK, Spooner G et al (2008) Curcumin restores corticosteroid function in monocytes exposed to oxidants by maintaining HDAC2. Am J Respir Cell Mol Biol 39:312-323

Miquel J, Bernd A, Sempere JM, Diaz-Alperi J, Ramirez A (2002) The curcuma antioxidants: pharmacological effects and prospects for future clinical use. A review. Arch Gerontol Geriatr 34:37-46

Moiseeva EP, Almeida GM, Jones GD, Manson MM (2007) Extended treatment with physiologic concentrations of dietary phytochemicals results in altered gene expression, reduced growth, and apoptosis of cancer cells. Mol Cancer Ther 6:3071-3079

Morimoto T, Sunagawa Y, Kawamura T, Takaya T, Wada H, Nagasawa A et al (2008) The dietary compound curcumin inhibits p300 histone acetyltransferase activity and prevents heart failure in rats. J Clin Invest 118:868-878

Mudduluru G, George-William JN, Muppala S, Asangani IA, Regalla $\mathrm{K}$, Nelson LD et al (2011) Curcumin regulates miR-21 expression and inhibits invasion and metastasis in colorectal cancer. Biosci Rep 31:185-197

Mukhopadhyay A, Bueso-Ramos C, Chatterjee D, Pantazis P, Aggarwal BB (2001) Curcumin downregulates cell survival mechanisms in human prostate cancer cell lines. Oncogene 20:7597-7609 
Myzak MC, Karplus PA, Chung FL, Dashwood RH (2004) A novel mechanism of chemoprotection by sulforaphane: inhibition of histone deacetylase. Cancer Res 64:5767-5774

Nafisi S, Adelzadeh M, Norouzi Z, Sarbolouki MN (2009) Curcumin binding to DNA and RNA. DNA Cell Biol 28:201-208

Negrini M, Ferracin M, Sabbioni S, Croce CM (2007) MicroRNAs in human cancer: from research to therapy. J Cell Sci 120:1833-1840

Neidle S (2001) DNA minor-groove recognition by small molecules. Nat Prod Rep 18:291-309

Ng TP, Chiam PC, Lee T, Chua HC, Lim L, Kua EH (2006) Curry consumption and cognitive function in the elderly. Am J Epidemiol 164:898-906

Nian H, Delage B, Pinto JT, Dashwood RH (2008) Allyl mercaptan, a garlic-derived organosulfur compound, inhibits histone deacetylase and enhances Sp3 binding on the P21WAF1 promoter. Carcinogenesis 29:1816-1824

Paluszczak J, Krajka-Kuzniak V, Baer-Dubowska W (2010) The effect of dietary polyphenols on the epigenetic regulation of gene expression in MCF7 breast cancer cells. Toxicol Lett 192:119-125

Patel KR, Brown VA, Jones DJ, Britton RG, Hemingway D, Miller AS et al (2010) Clinical pharmacology of resveratrol and its metabolites in colorectal cancer patients. Cancer Res 70:7392-7409

Penn L, White M, Oldroyd J, Walker M, Alberti KG, Mathers JC (2009) Prevention of type 2 diabetes in adults with impaired glucose tolerance: the European Diabetes Prevention RCT in Newcastle upon Tyne, UK. BMC Public Health 9:342

Pina IC, Gautschi JT, Wang GY, Sanders ML, Schmitz FJ, France D et al (2003) Psammaplins from the sponge Pseudoceratina purpurea: inhibition of both histone deacetylase and DNA methyltransferase. J Org Chem 68:3866-3873

Plummer SM, Holloway KA, Manson MM, Munks RJ, Kaptein A, Farrow $S$ et al (1999) Inhibition of cyclo-oxygenase 2 expression in colon cells by the chemopreventive agent curcumin involves inhibition of NF-kappaB activation via the NIK/IKK signalling complex. Oncogene 18:6013-6020

Pop EA, Fischer LM, Coan AD, Gitzinger M, Nakamura J, Zeisel SH (2008) Effects of a high daily dose of soy isoflavones on DNA damage, apoptosis, and estrogenic outcomes in healthy postmenopausal women: a phase I clinical trial. Menopause 15:684-692

Rafailov S, Cammack S, Stone BA, Katz AE (2007) The role of Zyflamend, an herbal anti-inflammatory, as a potential chemopreventive agent against prostate cancer: a case report. Integr Cancer Ther 6:74-76

Rahman I, Marwick J, Kirkham P (2004) Redox modulation of chromatin remodeling: impact on histone acetylation and deacetylation, NF-kappaB and pro-inflammatory gene expression. Biochem Pharmacol 68:1255-1267

Ramirez Bosca A, Soler A, Carrion-Gutierrez MA, Pamies Mira D, Pardo Zapata J, Diaz-Alperi J et al (2000) An hydroalcoholic extract of Curcuma longa lowers the abnormally high values of human-plasma fibrinogen. Mech Ageing Dev 114:207-210

Rasyid A, Lelo A (1999) The effect of curcumin and placebo on human gall-bladder function: an ultrasound study. Aliment Pharmacol Ther 13:245-249

Rasyid A, Rahman AR, Jaalam K, Lelo A (2002) Effect of different curcumin dosages on human gall bladder. Asia Pac J Clin Nutr 11:314-318

Ravindra KC, Selvi BR, Arif M, Reddy BA, Thanuja GR, Agrawal S et al (2009) Inhibition of lysine acetyltransferase KAT3B/p300 activity by a naturally occurring hydroxynaphthoquinone, plumbagin. J Biol Chem 284:24453-24464

Reddy BS, Sondhi SM, Lown JW (1999) Synthetic DNA minor groove-binding drugs. Pharmacol Ther 84:1-111
Richon VM, Emiliani S, Verdin E, Webb Y, Breslow R, Rifkind RA et al (1998) A class of hybrid polar inducers of transformed cell differentiation inhibits histone deacetylases. Proc Natl Acad Sci U S A 95:3003-3007

Rodenhiser D, Mann M (2006) Epigenetics and human disease: translating basic biology into clinical applications. CMAJ 174:341-348

Ruiz PA, Braune A, Holzlwimmer G, Quintanilla-Fend L, Haller D (2007) Quercetin inhibits TNF-induced NF-kappaB transcription factor recruitment to proinflammatory gene promoters in murine intestinal epithelial cells. J Nutr 137:1208-1215

Sadoul K, Boyault C, Pabion M, Khochbin S (2008) Regulation of protein turnover by acetyltransferases and deacetylases. Biochimie 90:306-312

Saleheen D, Ali SA, Ashfaq K, Siddiqui AA, Agha A, Yasinzai MM (2002) Latent activity of curcumin against leishmaniasis in vitro. Biol Pharm Bull 25:386-389

Sarkar FH, Li Y (2004) Cell signaling pathways altered by natural chemopreventive agents. Mutat Res 555:53-64

Satoskar RR, Shah SJ, Shenoy SG (1986) Evaluation of antiinflammatory property of curcumin (diferuloyl methane) in patients with postoperative inflammation. Int J Clin Pharmacol Ther Toxicol 24:651-654

Selvi BR, Pradhan SK, Shandilya J, Das C, Sailaja BS, Shankar GN et al (2009) Sanguinarine interacts with chromatin, modulates epigenetic modifications, and transcription in the context of chromatin. Chem Biol 16:203-216

Serafini M, Bellocco R, Wolk A, Ekstrom AM (2002) Total antioxidant potential of fruit and vegetables and risk of gastric cancer. Gastroenterology 123:985-991

Sharma RA, McLelland HR, Hill KA, Ireson CR, Euden SA, Manson MM et al (2001) Pharmacodynamic and pharmacokinetic study of oral Curcuma extract in patients with colorectal cancer. Clin Cancer Res 7:1894-1900

Sharma RA, Euden SA, Platton SL, Cooke DN, Shafayat A, Hewitt HR et al (2004) Phase I clinical trial of oral curcumin: biomarkers of systemic activity and compliance. Clin Cancer Res 10:6847-6854

Sheikh KD, Banerjee PP, Jagadeesh S, Grindrod SC, Zhang L, Paige $M$ et al (2010) Fluorescent epigenetic small molecule induces expression of the tumor suppressor ras-association domain family $1 \mathrm{~A}$ and inhibits human prostate xenograft. J Med Chem 53:2376-2382

Shishodia S, Aggarwal BB (2004) Nuclear factor-kappaB: a friend or a foe in cancer? Biochem Pharmacol 68:1071-1080

Shishodia S, Potdar P, Gairola CG, Aggarwal BB (2003) Curcumin (diferuloylmethane) down-regulates cigarette smoke-induced NF-kappaB activation through inhibition of IkappaBalpha kinase in human lung epithelial cells: correlation with suppression of COX-2, MMP-9 and cyclin D1. Carcinogenesis 24:1269-1279

Shishodia S, Amin HM, Lai R, Aggarwal BB (2005) Curcumin (diferuloylmethane) inhibits constitutive NF-kappaB activation, induces G1/S arrest, suppresses proliferation, and induces apoptosis in mantle cell lymphoma. Biochem Pharmacol 70:700-713

Shishodia S, Singh T, Chaturvedi MM (2007) Modulation of transcription factors by curcumin. Adv Exp Med Biol 595:127-148

Shoba G, Joy D, Joseph T, Majeed M, Rajendran R, Srinivas PS (1998) Influence of piperine on the pharmacokinetics of curcumin in animals and human volunteers. Planta Med 64:353-356

Shoskes D, Lapierre C, Cruz-Correa M, Muruve N, Rosario R, Fromkin B et al (2005) Beneficial effects of the bioflavonoids curcumin and quercetin on early function in cadaveric renal transplantation: a randomized placebo controlled trial. Transplantation 80:1556-1559 
Singh S, Aggarwal BB (1995) Activation of transcription factor NF-kappa B is suppressed by curcumin (diferuloylmethane) [corrected]. J Biol Chem 270:24995-25000

Smith LJ, Holbrook JT, Wise R, Blumenthal M, Dozor AJ, Mastronarde $\mathrm{J}$ et al (2004) Dietary intake of soy genistein is associated with lung function in patients with asthma. $\mathbf{J}$ Asthma 41:833-843

Son IH, Chung IM, Lee SI, Yang HD, Moon HI (2007) Pomiferin, histone deacetylase inhibitor isolated from the fruits of Maclura pomifera. Bioorg Med Chem Lett 17:4753-4755

Soni KB, Kuttan R (1992) Effect of oral curcumin administration on serum peroxides and cholesterol levels in human volunteers. Indian J Physiol Pharmacol 36:273-275

Stefanska B, Rudnicka K, Bednarek A, Fabianowska-Majewska K (2010) Hypomethylation and induction of retinoic acid receptor beta 2 by concurrent action of adenosine analogues and natural compounds in breast cancer cells. Eur J Pharmacol 638:47-53

Sun Y, Jiang X, Chen S, Price BD (2006) Inhibition of histone acetyltransferase activity by anacardic acid sensitizes tumor cells to ionizing radiation. FEBS Lett 580:4353-4356

Sun M, Estrov Z, Ji Y, Coombes KR, Harris DH, Kurzrock R (2008) Curcumin (diferuloylmethane) alters the expression profiles of microRNAs in human pancreatic cancer cells. Mol Cancer Ther 7:464-473

Surh Y (1999) Molecular mechanisms of chemopreventive effects of selected dietary and medicinal phenolic substances. Mutat Res 428:305-327

Taher MM, Lammering G, Hershey C, Valerie K (2003) Curcumin inhibits ultraviolet light induced human immunodeficiency virus gene expression. Mol Cell Biochem 254:289-297

Tili E, Michaille JJ, Adair B, Alder H, Limagne E, Taccioli C et al (2010a) Resveratrol decreases the levels of miR-155 by upregulating miR-663, a microRNA targeting JunB and JunD. Carcinogenesis 31:1561-1566

Tili E, Michaille JJ, Alder H, Volinia S, Delmas D, Latruffe N et al (2010b) Resveratrol modulates the levels of microRNAs targeting genes encoding tumor-suppressors and effectors of TGFbeta signaling pathway in SW480 cells. Biochem Pharmacol 80:2057-2065

Tsang WP, Kwok TT (2010) Epigallocatechin gallate up-regulation of miR-16 and induction of apoptosis in human cancer cells. J Nutr Biochem 21:140-146

Vareed SK, Kakarala M, Ruffin MT, Crowell JA, Normolle DP, Djuric Z et al (2008) Pharmacokinetics of curcumin conjugate metabolites in healthy human subjects. Cancer Epidemiol Biomarkers Prev 17:1411-1417

Vidali G, Boffa LC, Bradbury EM, Allfrey VG (1978) Butyrate suppression of histone deacetylation leads to accumulation of multiacetylated forms of histones $\mathrm{H} 3$ and $\mathrm{H} 4$ and increased DNase I sensitivity of the associated DNA sequences. Proc Natl Acad Sci U S A 75:2239-2243

Waldecker M, Kautenburger T, Daumann H, Busch C, Schrenk D (2008) Inhibition of histone-deacetylase activity by short-chain fatty acids and some polyphenol metabolites formed in the colon. J Nutr Biochem 19:587-593

Wargovich MJ (1997) Experimental evidence for cancer preventive elements in foods. Cancer Lett 114:11-17

Webb CM, Hayward CS, Mason MJ, Ilsley CD, Collins P (2008) Coronary vasomotor and blood flow responses to isoflavoneintact soya protein in subjects with coronary heart disease or risk factors for coronary heart disease. Clin Sci (Lond) 115:353-359

Winter J, Jung S, Keller S, Gregory RI, Diederichs S (2009) Many roads to maturity: microRNA biogenesis pathways and their regulation. Nat Cell Biol 11:228-234

$\mathrm{Xu}$ WS, Parmigiani RB, Marks PA (2007) Histone deacetylase inhibitors: molecular mechanisms of action. Oncogene 26:55415552

Yamada H, Takuma N, Daimon T, Hara Y (2006a) Gargling with tea catechin extracts for the prevention of influenza infection in elderly nursing home residents: a prospective clinical study. J Altern Complement Med 12:669-672

Yamada H, Tateishi M, Harada K, Ohashi T, Shimizu T, Atsumi T et al (2006b) A randomized clinical study of tea catechin inhalation effects on methicillin-resistant Staphylococcus aureus in disabled elderly patients. J Am Med Dir Assoc 7:79-83

Ying Y, Taori K, Kim H, Hong J, Luesch H (2008) Total synthesis and molecular target of largazole, a histone deacetylase inhibitor. J Am Chem Soc 130:8455-8459

Yoo CB, Jones PA (2006) Epigenetic therapy of cancer: past, present and future. Nat Rev Drug Discov 5:37-50

Yun JM, Jialal I, Devaraj S (2010) Epigenetic regulation of high glucose-induced proinflammatory cytokine production in monocytes by curcumin. J Nutr Biochem

Zhang K, Dent SY (2005) Histone modifying enzymes and cancer: going beyond histones. J Cell Biochem 96:1137-1148

Zhang J, Zhang T, Ti X, Shi J, Wu C, Ren X et al (2010) Curcumin promotes apoptosis in A549/DDP multidrug-resistant human lung adenocarcinoma cells through an miRNA signaling pathway. Biochem Biophys Res Commun 399:1-6

Zsila F, Bikadi Z, Simonyi M (2004) Circular dichroism spectroscopic studies reveal $\mathrm{pH}$ dependent binding of curcumin in the minor groove of natural and synthetic nucleic acids. Org Biomol Chem 2:2902-2910 